\title{
Teachers' Concerns and Uncertainties about the Introduction of CLIL Programmes
}

\author{
Víctor PAVÓN VÁzQuez \\ University of Cordoba \\ FERNANDO RUBIO \\ University of Huelva
}

Received: 6 June 2009 / Accepted: 20 November 2009

ISSN: $1697-7467$

\begin{abstract}
The implementation of content and language integrated learning (CLIL) means significant changes in the way in which teaching is planned, sequenced and carried out. The adoption of a new curriculum, which integrates linguistic and nonlinguistic material, as well as the linguistic and methodological needs that come with the introduction of this type of teaching, have generated feelings of concern and uncertainty. This paper reports those concerns and uncertainties in the Andalusian context, and strives for clarifying issues related to the theoretical assumptions, teaching implementation and creation of teaching units in CLIL.

Key words: educational policies, CLIL, methodology, plurilingual education, multilingual education.
\end{abstract}

\section{Preocupaciones del profesorado ante la implantación de programas AICLE}

RESUMEN: La implantación de la enseñanza integrada de lengua y contenidos (AICLE) supone la adopción de cambios significativos en la forma en la que la enseñanza es planificada, organizada y llevada a cabo. La adopción de un nuevo currículo basado en la integración de las áreas lingüísticas y de contenidos, así como los requisitos lingüísticos y metodológicos derivados de su implantación generan cierta preocupación y desconfianza. Este artículo aborda las causas que producen esta preocupación en el contexto de Andalucía, revisando los principios de la enseñanza AICLE en lo relativo a sus fundamentos teóricos y la problemática derivada de su aplicación.

Palabras clave: políticas educativas, AICLE, metodología, educación plurilingüe, educación multilingüe.

\section{INTRODUCTION}

Although there are some contexts in Spain where foreign language learning have had successful results (Navés \& Muñoz, 1999; Lasagabaster, 2001; Turell, 2001; Figueras, 2005; Goicoetxea et al., 2007; Elorza \& Muñoa, 2008), few people doubt that the problematic situation of foreign language learning in Spain requires a radical change in the way foreign languages are taught and learnt. Few doubt, either, that such a change will inevitably involve a comprehensive revision of the educational system, and that this revision should identify and 
analyse those factors that set Spain apart from other European countries. Why do students in some countries require less time to reach a higher level of foreign language competence than Spanish students? What type of teaching do they receive that may make the difference? These are probably the two most frequently asked questions about the whole situation.

Any changes to the educational system should be partly based on a detailed study of the variables that determine the effectiveness of the teaching methods that are being suggested. In the field of foreign language teaching, these variables are mainly related to the training of teachers, student's individual characteristics, the orientation of teaching methodology, the type of curriculum chosen, the materials that are available, and also importantly the social context in which this occurs. In Spain, two of these five variables seem to have been justifiably highlighted. A methodology has been chosen whose goal is to teach a foreign language with a communicative purpose, and the administration has opted for a curriculum that favours learning from an early age, promotes task-based learning, and provides the development of strategies and different skills. However, the teachers responsible for going into the primary classrooms are a product of an inadequately designed education system in which procedural competences are neglected, and in which little attention is paid to the teaching of foreign languages at an early age. At the same time, it provides secondary teachers with hardly any training in methodology or basic teaching practice to adolescents and post-adolescents. Other circumstances do not help either, with a frequently excessive number of students per class and with the majority of classrooms poorly equipped to take advantage of the huge quantity of teaching materials that are now available. Furthermore, we are faced with a social attitude, reflected in the treatment of foreign languages in the media, where there is total resistance to the broadcasting of films and television series in original version, to give two glaring examples, which seriously prejudices the learning of other languages. If we then add the method of testing in the University Entrance Exam (la prueba de selectividad) which only evaluates written skills, and which has ultimately become the 'hidden curriculum' of Secondary studies, we can get some ideas as to why the amount of hours students spend learning the foreign language is not even minimally fruitful to develop oral communication.

Faced with this bleak picture, some autonomous communities in Spain are putting forward plans advocating for multilingual teaching, as Plan de Fomento del Plurilingüismo in Andalusia, which take far reaching structural measures that entail decisions over educational policies which result in a total overhaul and modification of the global teaching of languages in every one of its facets (teachers, curriculum, social attitude, etc.). This educational proposal contemplates a bottom-up approach making use of certain innovative methodologies and that, through this, forces and, at the same time, supports a change in the established precepts with regard to the use of the foreign language in the classroom, basic training and methodology that requires teacher involvement, and the necessary restructuring of the curriculum. All of which could succeed in reaching this objective. And that is precisely what plurilingual education through Content and Language Integrated Learning (CLIL) seeks.

The education system in Andalusia, with regards to the teaching and learning of foreign languages, has decided, therefore, to outline a proposal based on the idea of transfer of knowledge and information in a foreign language as an indirect means of progressing and advancing the use of that foreign language. It concerns a teaching approach that is based on three great pillars. Firstly, it takes advantage of the irrefutable benefits of CLIL (Mohan, 1986; Stryker \& Leaver, 1993; Marsh, 1994; Short, 1994; Nikula \& Marsh, 1997; Snow \& Brinton, 
1997; Snow, 1998; Masih, 1999; Marsh, 2002; Wesche \& Skehan, 2002; Genesee, 2004; Pérez-Vidal \& Campanale, 2005; Dalton-Puffer \& Smit, 2007; Lasagabaster, 2008; Mehisto et al., 2008; Pavón \& Ávila, 2009; Ruiz \& Jiménez, 2009). Secondly, it involves the planning of teaching grounded in the creation of integrated curricula adapted to the realities of teaching and, finally, it promotes a thorough overhaul of the way in which non-linguistic, as well as linguistic subjects, are taught and learnt.

This article aims to analyse the fundaments of this proposal, applying the knowledge of what the teaching of language and content in an integrated way really means, and looking at the prerequisites for planning and organising this type of teaching, thus, taking a look at the profound change that the way in which teachers and students work is going to undergo; that is, we will look at the why, what and how of plurilingual education. The theoretical discussion issues have been chosen according to what teachers have reported as problematic or uncertain. The topics have been organized into three categories: theoretical assumptions, classroom methodology and Integrated Curriculum implementation. The analysis of these issues will hopefully clarify CLIL implementation matters and advise educational administrators and practitioners who are about to start a CLIL implementation program. This article serves as an amplifier of teachers'voices in many contexts of Andalusia towards CLIL implementation.

\section{Content And language integrated Learning}

\subsection{Teaching of content and language}

CLIL advocates the assimilation of the academic content of non-linguistic subjects through the medium of a foreign language and, through this, help to encourage an advance in knowledge and use of that foreign language by the students (Short, 1991; Baetens Beardsmore, 2002; Coyle, 2007). It involves a style of teaching that does not focus specifically on the progression of the foreign language but sees it as an opportunity to encourage its use and, in this way, promote its development (Krahnke, 1987:65; Marsh, 1994:23; Richards \& Rodgers, 2003:201).

In line with the principles that define it, this teaching approach is beneficial as a result of the following (Ayrei, 2004; Coyle, 2004; Marsh, 2008):

a) the learning of a foreign language is seen as more attractive when we use linguistic resources that offer a means of acquiring information;

b) the use of the foreign language has a purpose;

c) the learning of a foreign language is better when the information that is being acquired is seen to be interesting, useful, and has a clear end goal.

However, despite the fact that, at first sight, it seems that the only goal of this type of teaching is the promotion of linguistic competence, it should be pointed out that it does not neglect the main aim of teaching, which is that students develop competencies and acquire the different content necessary for their academic education. It is an important point, however, that sometimes the adaptation of a curriculum that requires the integration of the content of different subjects so that they are taught in a foreign language can provoke a certain amount of mistrust in those who believe that such adaptation will inevitably cause a reduction in the amount of content of non-linguistic subjects (Met, 1998; Stoller, 2004; Lorenzo, 2007). 
Amongst the objectives of CLIL that stands out is that it advocates the obtaining of different knowledge and skills, according to what the subject is. Furthermore, it pays special attention to the development of academic skills that are determined by the age and cognitive and linguistic abilities of the students (Dewaele, 2007; Merisuo-Storm, 2007). Finally, it pays special attention also to socio-cultural strategies, explicitly fostering activities which lead to the promotion of positive attitudes towards the speakers of the foreign language and towards their culture (Lantolf, 2000; Pérez-Vidal, 2008).

CLIL has a long tradition in numerous countries where it forms an essential part of bilingual programs and that its effectiveness has been confirmed (Cenoz \& Valencia, 1994; Lasagabaster, 1998; Martin, 1999; Dalton-Puffer, 2002; Dalton-Puffer \& Nikula, 2006), although many of these programs have been conducted in bilingual settings, which are very different from settings where a foreign language is taking place. Its benefits are not only found in the unquestionable improvement in terms of foreign language learning, but those benefits are even more obvious in the development of cognitive abilities in the students. They are expected to use different cognitive processes to those used to assimilate content in their mother tongue (Kowal \& Swain, 1997; Jäppinen, 2005; Gallagher \& Morilla, 2009; Salaberri, 2009), by which learning is converted into a creative process since, through the use of the foreign language, they access greater and more complex information. And, of course, it is a great help in improving linguistic competence that students receive a greater number of hours of exposure to the foreign language; but above all, this increase in quantity is accompanied by a similar increase in quality, having contact with the foreign language in an academic context, a contact which brings the benefit of a meaningful use of the language as a means of accessing information.

In addition, the teaching of language and content introduces a big change to the role given to teachers and students. According to Stryker and Leaver (1993:293), the teacher must:

a) change the style of instruction in the classroom;

b) make use of group work and cooperative strategies;

c) identify prior linguistic knowledge and skills;

d) help the student to develop strategies to cope with different situations;

e) use suitable techniques for error correction;

f) develop and maintain high levels of self-confidence in the students;

All this means at the beginning a methodological revolution (see, for example, proposals like David Marsh' "CLIL Matrix": http://www.ecml.at/mtp2/CLILmatrix/EN/qMain.html), as students are going to be exposed to some content presented in a language in which they do not have the same fluency as with their mother tongue. So, teaching staff will find themselves forced to change a system of teaching, in which the transmission of information has traditionally been put first as a lecture format, for another system which promotes the understanding and assimilation of contents based on heuristic activity and discovery.

The students, for their part, see a change in their learning habits and general classroom behaviour since this teaching will mean an increase and improvement in the following areas:

a) the promotion of learner autonomy;

b) the use of cooperative learning;

c) participation in the selection of themes and activities;

d) commitment to a new system of learning;

e) the need to be prepared psychologically and cognitively; 
These changes permit students to join in and take part in the process of teaching and learning in a more active way. They will be expected, due to the inherent difficulties of the acquisition of information in a foreign language, to participate, on a voluntary or involuntary basis, in the selection of content and activities according to their ability and skills (linguistic and non-linguistic) and give up their passive attitude, where they only listen to what they have to do, and understand that they are dealing with a different type of learning from what they are used to and that they have to take an active part.

\section{2. "Teach in" a foreign language or "teach through" a foreign language}

In accordance to what some previous studies have reported (see Freeman \& Freeman, 1997; Escobar \& Pérez-Vidal, 2004; Marsh \& Wolff, 2006; Bowler, 2007), we have also acknowledged a set of CLIL implementation problems, namely structural (related to organization [Mehisto, 2009] and curricular sequencing), linguistic (related to the basic competence of teachers and students), and attitudinal (on the part of the staff responsible for teaching).

Taking the following quote as a starting point: "The saying 'all teachers are English teachers' became familiar to all professionals in the teaching world. Like other multidisciplinary proposals, it did not achieve the influence in the classrooms that its supporters hoped for." (Richard \& Rodgers, 2003:202); serves to illustrate the first problem that the teaching of language and content faces, which is none other than the consideration that all teachers, including those of non-linguistic subjects, are responsible for controlling and regulating the linguistic progression of the students. As such, this teacher profile accepts the premise that they must be involved in their students' acquisition of the foreign language in the sense that they provide them with systematic linguistic support to help them acquire academic information. In line with this perspective, and referring back to the play on words in the heading for this section, the foreign language becomes a simple tool for accessing content, a tool that has to be watched closely so that it is used correctly and carries out its function of transmitter of information. Teaching is made "in" a foreign language and not through it, if emphasis is placed on linguistic accuracy with the idea that if there is no such accuracy, there can be no understanding. On the other hand, teaching "through" a foreign language implies, not only that the foreign language be utilized in an effective and correct a way to access those contents, but it also recognises that the use of "incorrect" forms is not an impediment to the understanding of an action or process and it is possible to analyse, deduce, create hypotheses and memorise without having to possess a correct version of the language being used. This means that the creative use of language could be the key to understanding, and use is not necessarily tied to accuracy. The objective of teaching is diverted to the comprehensive transmission of information, from the use made of the language, always and when, obviously, that use ensures understanding of what is being explained or discussed.

The image that is provoked is that of content teachers having control for linguistic development, and the foreign language being relegated to be used as a secondary tool. This only adds to the tremendous pressure on teaching staff who, in many cases, have difficulty manipulating the foreign language and, for that reason, they should not be asked to assume such a difficult role. It is not recommended, either, to ask for this to teachers with a broad knowledge of the foreign language; firstly, because it goes against the main principle of teaching language and content, in that content is taught through the foreign language, and secondly, 
because doing so would suppose dedicating a huge amount of class time and get in the way of the students' assimilation of academic content.

\section{Changes in methodology as a result of Content and language INTEGRATED TEACHING}

One of the principle pillars on which plurilingual teaching rests is the approach to methodology. The principles that determine a method of teaching based on the learning of language and content in unison is shaped by the way in which the Integrated Curriculum is structured, but its effectiveness depends on a correctly implemented methodology (Short, 1991; Echevarría et al., 2000; Marsh, 2001; Pavón, 2007).

The principle that would have stood out in choosing a methodology associated with CLIL is that the methodological changes that it implies are going to have a very positive influence on two of the most common important aspects of learning a foreign language: the development of oral skills and the increased motivation of students. Firstly, the use of the language as a tool to access the meaning of what is being studied in the classroom is largely oral. Students are expected to use their skills of oral expression to achieve an understanding of the message to which they are being exposed. This is a point of great importance as it is in this area of communicative skills that there is the greatest deficit and, of course, students benefit from a significant increase in their ability to express themselves orally with more fluency and accuracy. Secondly, the methodology applied for this type of teaching has a direct affect on the psychoaffective characteristics of the students (Merisuo-Storm, 2007; Mehisto, Marsh, Frigols, 2008). On the one hand, the promotion of positive attitudes with regard to the speakers and their culture will lead directly to an increase in terms of motivation (Short, 1994; Lantolf, 2000, Ávila, 2009), making the students appear more motivated and more interested in the themes covered in the classroom. And, on the other hand, the students acquire an awareness that better and more accurate use of the language may provide greater opportunities to increase their knowledge and satisfy their interest and curiosity. The increase in understanding, and the ability to access content, themes and increasingly complex concepts, are inversely proportional to the feeling of effort derived from language learning.

The methodology in which this type of educational proposal is based varies according to the type of teacher charged with applying it in the classroom, namely teachers of linguistic areas and teachers of non-linguistic areas. It has to be noted that this type of teaching should be carried out by teachers with an open mind to teaching, that is, with a non-traditional view of teaching and with a positive attitude to use quite varied approaches to methodology. Since the objective is that the content of non-linguistic areas is conveyed through a foreign language, the main work rests on the shoulders of teachers of non-linguistic areas, although that is not to say that teachers of linguistic areas play a secondary role given that, as well as having to achieve their own curricular objectives, they have to reinforce and consolidate the assimilation of the academic contents taught in the foreign language.

This work requires that the teachers of non-linguistic areas have, as well as knowledge of their own subject, sufficient linguistic competence to be able to pass on certain academic content in a foreign language. On occasions, the lack of adequate knowledge of the language 
creates great unease among teachers. This is the situation that we find with the introduction of plurilingual education in Andalusia, and which, in several cases, has led to the suggestion that it would be a better option to train foreign language teachers as experts in content. On this point, we believe that, apart from the fact that such training would be a time-consuming task, it makes no sense in that, intentionally or not, it shows that the people who are following this idea have a mistaken view of what CLIL means. It is clear in such a proposal that it puts too much emphasis on the language and not on the methodology. We should also remember that one of the goals of the Plan to Promote Plurilingualism is to train teachers in multilingual skills: "Bilingual teaching offers teachers a chance to continue to learn and develop professionally in a way that is key to the learning of students and to their quality as a professional." (Pavón et al., 2005:18).

The effectiveness of CLIL does not only rest on whether the teachers charged with teaching the subjects have a certain level of linguistic excellence, but also on a real organisation together with sequencing of the curriculum and, above all, that the correct methodology is used in the two areas, linguistic and non-linguistic. Plurilingual teaching offers a series of corrective measures to relieve potential problems that might arise with regard to the basic training and methodology of teachers. However, the necessity to improve the methodological training of teachers of non-linguistic areas, with regard to the use of a foreign language, must be stressed. It is not enough to increase the basic knowledge of the foreign language, but teachers need to be given the skills necessary to be able to use the benefits of their linguistic knowledge on a pedagogic level: "The teacher of whatever material is being taught in an L2, should not only update his linguistic knowledge to a standard and recognized level of fluency but should develop a different linguistic sensitivity to be able to adapt the contents to the new language and develop teaching procedures that make it possible for the student to learn." (Pavón et al., 2005:18). Teachers of content areas should require basic knowledge of the didactics of the foreign language and, therefore, should make an effort to train in methodology, as one of the prerequisites of this type of teaching is a change in methodology to one of participative and communicative classes.

This emerging view of methodology is crucial for the sequencing of objectives in CLIL. All the good intentions will come to nothing if there is not a methodological agreement among teachers over the need for a change from instruction-type classes, in which academic content is taught in the same way in which it is taught in the mother tongue, to participative classes, in which the students use the foreign language to access information. It is not about teaching "the same" in another language, but deals with promoting the assimilation of content through the use of different techniques (identification, classification, inference, prediction, recognition, comparison, etc.), the encouragement of corporative study strategies, and the search for alternative means of supplying input (internet, magazines, newspapers, brochures, instructions, scientific journals, etc.) that help the understanding of the material (García-Mayo, 2009). To achieve this, a widely spread idea needs to be stamped out among non-linguistic teachers. That idea is that lessons given in the foreign language are of the type that "summarize" the content that has already been explained in the mother tongue and is then repeated in a foreign language in the belief that in this way the academic contents are assimilated and not just stagnant or prejudiced because of the low linguistic competence of the students in the foreign language. This is an option that, without a doubt, shows certain linguistic benefits, those related to the consolidation of vocabulary above all, but it is totally against the principle of CLIL. The great 
challenge that faces teachers of non-linguistic areas is the change in favour of a methodology that emphasizes the use of activities that promote the linguistic competence of students with a communicative end goal, and whose objective is not to teach "things", but to teach to understand, to retain and to use.

\section{The CREATION OF INTEgRated DIDACTIC UNITS}

Once the basic principles for the introduction of this new methodological approach have been determined and the urgent need for a coordinated approach by all teachers has been recognised, we move on to the physical element through which these two important variables in the process of CLIL are shaped: the creation of didactic units. In contrast with a closed Integrated Curriculum, in which the selections of goals and the organisation and sequencing of contents seems to be pre-determined, the open Integrated Curriculum is based on the adaptation of the curriculum within the different subjects and the didactic unit is the corner stone of its organizational strategy. The creation of integrated didactic units, in which the teachers involved in plurilingual teaching contribute to the goals and common contents of their linguistic and non-linguistic subjects, becomes the central element of CLIL.

By definition, the didactic units should be open and flexible and as such should be integrated in character; however, it is possible to aim for a common basic organization that is structured around the following elements:

1. Basic Information: name of centre, departments and teachers involved, the relationship between the coordinated subjects, class, age, and, above all, the level of the students with respect to the Common European Framework.

2. Title of the unit: the widest possible heading that allows the inclusion of common themes from the different subjects.

3. Transverse themes: the relationship between themes that are studied in coordination in the different subjects (the term "transverse" should not be confused with the Spanish term "ejes transversales", meaning cross-curriculum contents; transverse themes is related to themes from different subjects that are going to be approached together).

4. General objectives: made up of the objectives for that stage.

5. Specific objectives: could refer to disciplinary and academic elements, or be based on competencies, skills and strategies.

6. The contents and sequencing of the unit: specifics about the content, conceptual, procedural and attitudinal aspects (this should favour the selection of visual and practicaltype content, the exposure to the foreign language, and promotion of its use as a means of accessing knowledge), and the timing of the sessions.

7. Design and sequence of the activities: the relationship between the contents and their timing; priority should be given to activities that favour an effective (oral and written) use of the language in an academic context.

8. Evaluation: criteria for evaluation and the type of instruments used to evaluate: oral interviews, written quizzes or tests, individual and group observation, etc.

9. Materials: textbooks, specialist publications, web pages (favouring the interactive type rather than the merely informative type), multimedia resources, materials generated by teachers, etc. 
10. Bibliography: References of works used by the teacher and publications for students to consult.

The design of didactic units could present certain problems in cases where there has been no previous experience of adapting the curriculum between linguistic and non-linguistic areas, and between the different subjects. Looking at the work done by teachers involved in the Plan to Promote Plurilingualism, in Andalusia, on the creation of didactic units and an integrated curriculum, we can identify some of those problems. One of them is related to the role that linguistic material versus non-linguistic material, or vice versa, should occupy in the work of coordination. That is to say, it is difficult to coordinate and integrate the objectives and content of the subjects taught in the mother tongue and foreign language with the rest of the content subjects. In the creation of integrated didactic units the linguistic material, and that of the foreign language above all, should be coordinated in a way that helps with the non-linguistic subjects, supporting the effective use of the language as a means of accessing the academic content, as well as trying to reach its specific objectives (López, 2009). For example, the foreign language teachers should coordinate with the content teachers to contribute towards and support the correct use of the linguistic resources. That is not to say that the selection and organization of the contents of the foreign language should be subject to the needs of the nonlinguistic subjects, but that an effort should be made to adapt the sequence of those contents to those needs.

Another of the concerns that teachers have reported to us relates to the selection of objectives, particularly with the difficult task of integrating the objectives of such a diverse range subjects, in particular. It is evident that the specific objectives of linguistic and nonlinguistic subjects are different, just as they are between different non-linguistic subjects. For that reason, the work of coordination should concentrate on finding the common elements within the wide range of objectives. But, without a doubt, the element that usually causes most controversy among teachers is the decision about whether to include linguistic goals in nonlinguistic subjects or not. Some teachers choose to include them with the idea that the use of the foreign language is common to all non-linguistic subjects and, therefore, the intent to acquire the linguistic resources necessary to teach the contents of their subject, should be made explicit in their planning. This way of thinking results from a misinterpretation of the meaning of CLIL. As explained in section 2.2., the main objective of the non-linguistic subjects is to facilitate the learning of academic contents through the use of a foreign language, and it is the linguistic subjects that should aim to provide the linguistic resources necessary to achieve this. The ideal would be that there is close coordination between the teachers of both areas to ensure that the linguistic demands for the students in the content subjects are completely covered, as mentioned in section 3. Notwithstanding this, if linguistic goals are evaluated they should mean only extra-credit for students' marks (BOJA 2006:13).

The identification and selection of contents is another key element in the design of didactic units. The selection is closely linked to the search for "transverse themes", a collection of pivotal themes that should be present in the different contributions from all the subjects. It should be pointed out that the main characteristic of what is included in an integrated didactic unit is that contents should be chosen primarily for their emotive value, in that they awaken the interest of the students. The contents should also be chosen in line with the linguistic and non-linguistic needs of the students. In the case of the linguistic needs, it is extremely important, in the first place, that the contents chosen to be taught in a foreign language do not require 
the use of complex linguistic structures. To achieve this, contents that are compatible with the learning of languages should be looked for. On the other hand, the selection of contents should take into consideration the previous experience of the students, so the search for familiar contents would obviously help their assimilation at the same time as creating greater opportunities for the use of the language. Finally, special attention should be paid to ensure that the amount of material to be covered is adequate for the time allowed. That is that special care should be taken to avoid adding the difficulty of understanding the contents, and a rush to cover them, to the innate difficulty of understanding explanations in a foreign language.

One of the main problems that teachers repeatedly report is the presentation of the contents of different subjects in an integrated way. CLIL does not advocate in any way that there be an obligation to manufacture common content at any price between the different subjects, forcing an unrealistic and artificial selection, but defends a sensible search for similar content or that there are common elements, to allow them to be approached jointly through various, but not necessarily all, the subjects involved. It could be that this representation of common contents might cause a fear that the logical sequence in which contents should be presented within the subject will be broken. However, it is an unfounded fear in that the selection of common content does not necessarily imply that they have to be dealt with in parallel and at the same time, that is to say that it is not necessary to cover them in unison in each one of the related subjects. On the other hand, it would be an impossible task to achieve given the different time assigned to different subjects and, obviously, because it would threaten the internal logic of each of those subjects.

\section{Conclusion}

This paper has dealt with some of the most common concerns and uncertainties teachers have reported in the first stages of CLIL implementation. Theoretical assumptions, classroom methodology and Integrated Curriculum implementation are the main categories where most problems are found. For instance, the use of the native versus the foreign language in the classroom, the roles of linguistic area teachers versus non-linguistic area teachers, the coordination of the subjects, or the flexibility in the creation of the didactic units. The introduction of CLIL provides an opportunity to produce a methodological revolution in order to facilitate the development of oral skills and the increased motivation of students. Although this article reports those uncertainties that teachers have described in the process of CLIL implementation, it would not be fair to leave unsaid that those teachers in the Andalusian context have also showed a very positive attitude towards this challenge and have proved an enormous dose of effort to make it happen.

\section{REFERENCES}

Airey J. (2004). "Can you teach it in English? Aspects of the language choice debate in Swedish higher education", in Wilkinson, R. (ed.), Integrating content and language. Meeting the challenge of a multilingual higher education, Maastricht: Maastricht University, 97-108. 
Ávila, J. (2009). "Factores afectivos: la piedra de toque del AICLE", in V. Pavón and J. Ávila (eds.), Aplicaciones didácticas para la enseñanza integrada de lengua y contenidos. Sevilla: Consejería de Educación de la Junta de Andalucía-Universidad de Córdoba, 91-111.

Baetens Beadsmore, H. (1993). European Models of Bilingual Education. Clevendon: Multilingual Matters.

Baetens Beardsmore, H. (2002). "The significance of CLIL", in D. Marsh (ed.) CLIL/EMILE. The European Dimension. Actions, Trends and Foresight Potential. Jyväskylä: University of Jyväskylä, 20-27.

BOJA (Boletín Oficial de la Junta de Andalucía). 24 de Julio de 2006, 13.

Bowler, B. (2007). "The Rise and Rise of CLIL" in New Standpoints, Sep-Oct 2007: 7-9.

Brinton, D., Snow, M., Wesche, M. (1989). Content-based Second Language Instruction. New York: Newbury Press.

Brinton, D.M., Master, P. (eds.) (1997). New Ways in Content-Based Instruction. New York: Newbury House.

Cenoz, J., Valencia, JF. (1994). "Additive trilingualism: evidence from the Basque Country", in Applied Psycholinguistics, 15: 195-207.

Council of Europe. (2001). Common European Framework of Reference for Languages: Learning, Teaching, Assessment. Cambridge: Cambridge University Press.

Coyle, D. (2004). "Supporting students in CLIL contexts: Planning for effective classroom", in J. Masih (ed.), Learning through a Foreign Language. Lancaster: CILT, 40-54.

Coyle D. (2007). "Content and language integrated learning: towards a connected research agenda for CLIL pedagogies", in International Journal of Bilingual Education and Bilingualism, 10: 543-562.

Dalton-Puffer, C. (2002). "Content and language integrated learning in Austrian classrooms: applied linguistics takes a look", in VIEWS 11/: 4-26.

Dalton-Puffer, C., Nikula, T. (2006). "Pragmatics on content-based instruction: Teacher and students directives in Finnish and Austrian classrooms", in Applied Linguistics 27 (2): 241-267.

Dalton-Puffer, C., Smit, U. (2007). Empirical Perspectives on CLIL: Classroom Discourse. Frankfurt: Peter Lang.

Dewaele, J.M. (2007). "Predicting language learners' grades in the L1, L2, L3 and L4: the effect of some psychological and sociocognitive variables", in International Journal of Multilingualism, 4: 169-197.

Echevarría, J., Vogt, M.E., Short, D.J. (2000). Making Content Comprehensible for English: The SIOP Model. London: Pearson Education.

Elorza, I., Muñoa, I. (2008). "Promoting the minority language through integrated plurilingual language planning: the case of the Ikastolas", in J. Cenoz (ed.), Teaching through Basque: Achievement and Challenges. Clevendon: Multilingual Matters, 85-101.

Escobar, C., Pérez-Vidal, C. (2004). "Teacher education for the implementation of a content and language integrated approach (CLIL) in the school system", in Wilkinson, R. (ed.), Integrating content and language. Meeting the challenge of a multilingual higher education. Maastricht University, 402-415.

Figueras, N. (ed.) (2005). CLIL in Catalonia, from Theory to Practice. Asociación de Profesores de Inglés de Calaluña, APAC.

Freeman, D., Freeman, Y. (1997). "Whole language teaching and content-based instruction: Are they compatible?", in M.A. Snow and D.M. Brinton (eds.), The Content-Based Classroom. London: Longman, 351-354.

Gallagher, E., Morilla, C. (2009). "A new CLIL method: AMCO and the practical use of multiple inteligences in the classroom”, in V. Pavón and J. Ávila (eds.), Aplicaciones didácticas 
para la enseñanza integrada de lengua y contenidos. Sevilla: Consejería de Educación de la Junta de Andalucía-Universidad de Córdoba, 131-151.

García-Mayo, P. (2009). "El uso de tareas y la atención a la forma del lenguaje en el aula AICLE", in V. Pavón and J. Ávila (eds.), Aplicaciones didácticas para la enseñanza integrada de lengua y contenidos. Sevilla: Consejería de Educación de la Junta de Andalucía-Universidad de Córdoba, 55-73.

Genesee, F. (2004). "Integrating language and content: Lessons from immersion". Educational Practice Report 11. Washington, DC: Center for Applied Linguistics, National Center for Research on cultural Diversity and Second language Learning.

Goicoetxea, M.J., Balarín, A. Fontal, R. (2007). "Una aproximación a la enseñanza de lenguas en la Unión Europea", in Perspectiva CEP 13. Sevilla: Consejería de Educación de la Junta de Andalucía, 7-43.

Jäppinen, A.K. (2005). "Thinking and content learning of mathematics and science as cognitional development in content and language integrated learning (CLIL): Teaching through a foreign language in Finland", in Language and Education 19, 147-168.

Kowal, M., Swain, M. (1997). "From semantic to syntactic processing. How can we promote it in the immersion classroom?", in R.K. Johnson and M. Swain (eds.), Immersion Education: International Perspectives. Cambridge. Cambridge University Press, 284-309.

Krahnke, K. (1987). Approaches to Syllabus Design for Foreign Language Teaching. New York: Prentice Hall.

Lantolf, J.P. (ed.) (2000). Sociocultural Theory and Second Language Learning. Oxford: Oxford University Press.

Lasagabaster, D. (1998). "Learning English as an L3", in ITL Review of Applied Linguistics, 121122: 51-84.

Lasagabaster, D. (2001). "Bilingualism, immersion programmes and language learning in the Basque Country", in Journal of Multilingual and Multicultural Development, 22/5: 401-425.

Lasagabaster, D. (2008). "Foreign language competence in content and language integrated courses", in The Open Applied Linguistics Journal, 1: 30-41.

López, E.M. (2009). "Cómo abordar la elaboración del Currículo Integrado de las Lenguas y de las Áreas No-lingüísticas”, in V. Pavón and J. Ávila (eds.), Aplicaciones didácticas para la enseñanza integrada de lengua y contenidos. Sevilla: Consejería de Educación de la Junta de Andalucía-Universidad de Córdoba, 201-218.

Lorenzo, F. (2007). "An analytical framework of language integration in L2 Content-based Courses: The European dimension", in Language and Education, 21, no. 6: 502-514.

Marsh, D. (1994). Bilingual Education and Content and Language Integrated Learning. International Association for Cross-cultural Communication. Language Teaching in the Member States of the European Union (Lingua). Paris. University of Sorbonne.

Marsh, D. (2002). Content and Language Integrated Learning. The European Dimension. Jyväskyla: University of Jyväskyla Press.

Marsh, D. (2008). "Language awareness and CLIL.”, in Cenoz J., Hornberger NH. (eds.), Encyclopedia of language and education. Knowledge about language, 2nd edition, Volume 6, New York: Springer, 233-246.

Marsh, D., Wolff, D. (2006). Diverse Contexts-Converging Goals: CLIL in Europe. Frankfurt: Peter Lang.

Marsh, D. et al. (2001). Profiling European CLIL Classrooms. Jyväskylä: University of Jyväskylä

Martin, E. (ed.). (1999). TEL2L Materials. Teaching Content Through a Foreign Language: Case Studies of Current Practices in Mainstream Bilingual Education in France, Germany, Spain and the UK. Verlag Empirische Pädagogik, Landau. 
Masih, J. (1999). Learning Through a Foreign Language. Lancaster: CILT.

Mahisto, P. (2009). "Managing multilingual education: structuring stakeholders dialogue and collaboration", in V. Pavón and J. Ávila (eds.), Aplicaciones didácticas para la enseñanza integrada de lengua y contenidos. Sevilla: Consejería de Educación de la Junta de Andalucía-Universidad de Córdoba, 9-27.

Mehisto, P., Marsh, D., Frigols; M.J. (2008). Uncovering CLIL. London: Macmillan.

Merisuo-Storm, T. (2007). "Pupils' attitudes towards foreign-language learning and the development of literacy skills in bilingual education", in Teaching Teacher Education 2007; 23: 226-235.

Met, M. (1998). "Curriculum decision making in content-based language teaching", in J. Cenoz and F. Genesee (eds.), Beyond Bilingualism: Multilingualism and Multilingual Education. Clevendon: Multilingual Matters, 35-63.

Mohan, B. (1986). Language and Content. Reading, MA: Addison-Wesley.

Naves, T., Muñoz, C. (1999). "Implementation of CLIL in Spain”, in Marsh, D. \& Langé, G. (eds.), Implementing Content and Language Integrated Learning. ER-paino \& Jyväskylän yliopistapaino, Jyväskyla; Finland, 145-158.

Nikula, T., Marsh, D. (1997). Language and Content Integrated Learning in the Primary and Secondary School Sector. Helsinki: National Board of Education.

Nunan, D. (1996). Designing Tasks for the Communicative Classroom. Cambridge: Cambridge University Press.

Pavón, V. (2007). "La implantación de la enseñanza plurilingüe en Andalucía: hacia una nueva propuesta metodológica y curricular", in Perspectiva CEP 13. Sevilla: Consejería de Educación de la Junta de Andalucía, 45-60.

Pavón, V., Hernández, H., Lorenzo, F, Hengst, H. (2005). "Borrador para la elaboración del Currículo Integrado", Plan to Promote Multlingualism, Junta de Andalucía, available in: http:// www.juntadeandalucia.es/averroes/plurilinguismo/curriculo/borradorcil.pdf

Pavón, V., Ávila, J. (eds.) (2009). Aplicaciones didácticas para la enseñanza integrada de lengua y contenidos. Sevilla: Consejería de Educación de la Junta de Andalucía-Universidad de Córdoba.

Pérez-Vidal, C. (2008). "El enfoque integrado de contenido y lenguas en Europa. Principios sociales, educativos y psicolingüísticos", in Aula de Innovación Educativa, 168: 7-16.

Pérez-Vidal, C. (ed.), Campanale, N. (2005). Content and Language Integrated Learning (CLIL) in Europe. Barcelona: Printulibro Intergroup.

Plan de Fomento del Plurilingüismo, Consejería de Educación, Junta de Andalucía. http:// www.juntadeandalucia.es/averroes/plurilinguismo/

Richards, J.C., Rodgers, T.S. (2003). Approaches and Methods in Language Teaching. Cambridge: Cambridge University Press.

Ruiz, Y., Jiménez, R. (2009). Content and Language Integrated Learning (CLIL):Evidence from Research in Europe. Clevendon: Multilingual Matters.

Salaberri, S. (2009). "Inteligencias múltiples y desarrollo de destrezas orales", in V. Pavón and J. Ávila (eds.), Aplicaciones didácticas para la enseñanza integrada de lengua y contenidos. Sevilla: Consejería de Educación de la Junta de Andalucía-Universidad de Córdoba, $113-130$

Short, D.J. (1991). "Integrating language and content instruction: strategies and techniques", in NCBE Program Information Guide Series, No. 7, Fall 1991: 1

Short, D.J. (1994). "Expanding middle-school horizons: Integrating language, culture and social studies", in TESOL Quarterly 28: 581-608.

Snow, M.A. (1998). "Trends and issues in content-based instruction", in Annual Review of Applied Linguistics 18: 243-267. 
Snow, M.A., Brinton, D.A. (eds.). (1997). The Content-Based Classroom:Perspectives on Integrating Language and Content. New York: Longman.

Stoller, F.L. (2004). "Content-based instruction: Perspectives on curriculum planning", in Annual Review of Applied Linguistics 24: 261-283.

Stryker, S., Leaver, B. (1993). Content-Based Instruction in Foreign Language Education. Washington D.C.: Georgetown University Press.

Turell, M.T. (2001). Multilingualism in Spain. Clevendon: Multilingual Matters.

Wesche, M.B., Skehan, P. (2002). "Communicative, task-based, and content-based instruction". R.B. Kaplan (ed.), The Oxford Handbook of Applied Linguistics. New York: Oxford University Press, 207-228. 